\title{
STUDY OF A COMMUNITY OF FLIES AT DIFFERENT ALTITUDES IN THE SERRA OF CALDAS NOVAS PARK, GOIÁS, BRAZIL
}

\author{
MARCHIORI, C. H. \\ Instituto Luterano de Ensino Superior de Itumbiara - ILES-ULBRA, \\ Av. Beira Rio, 1001, C. P. 23-T, CEP 75500-000, Itumbiara, GO, Brazil \\ Correspondence to: Carlos Henrique Marchiori, Instituto Luterano de Ensino Superior de Itumbiara - ILES-ULBRA, \\ Av. Beira Rio, 1001, C. P. 23-T, CEP 75500-000, Itumbiara, GO, Brazil, e-mail: pesquisa.itb@ulbra.br
}

Received March 22, 2005 - Accepted April 19, 2005 - Distributed August 31, 2006

Flies included in the infra-order Muscomorpha (Guimarães et al., 2001) have medical and veterinary importance since they may produce myiasis and act in carrying pathogens to man and animals (Ferreira, 1978; Marcondes, 2001). They have been found to carry more than 100 species of disease-causing organisms such as bacteria, protozoa and helminths (Greenberg, 1971). The aim of the present study is to analyze the type of substrate utilized by and the influence of altitude variation on synanthropic flies.

The study was conducted from August 2003 to July 2004 in the Serra de Caldas Novas Park, located within the municipality of Caldas Novas, state of Goiás $\left(17^{\circ} 44^{\prime} \mathrm{S}\right.$ " and $\left.48^{\circ} 37^{\prime} \mathrm{W}\right)$. Adult flies were collected by means of traps constructed using cans of matt black color, measuring around $19 \mathrm{~cm}$ in height by $9 \mathrm{~cm}$ in diameter. These had two slat-type openings located in the lower third of the cans to allow insects to enter. Nylon funnels were attached to the tops of the cans with their narrow bases pointing downwards into the cans. The upper, wide ends of the funnels were open and had plastic bags wrapped around them. The flies were collected by removing these plastic bags containing the flies. Human feces, fish, bovine liver, chicken and fruit served as bait for attracting the flies. These were deposited inside the cans, on a layer of earth. Ten traps were used at the altitude of $740 \mathrm{~m}\left(17^{\circ} 46^{\prime} 04^{\prime \prime} \mathrm{S}\right.$ and $\left.48^{\circ} 39^{\prime} 35^{\prime \prime} \mathrm{W}\right)$ and ten at the altitude of $1,000 \mathrm{~m}\left(17^{\circ} 46^{\prime} 52^{\prime \prime} \mathrm{S}\right.$ and $48^{\circ} 41^{\prime}$ $\left.14^{\prime \prime} \mathrm{W}\right)$. There were two traps for each type of bait, and these traps were hung on trees at a height of one meter above the ground and two meters from each other. The insects collected were taken to the laboratory, killed using ethyl ether and conserved in $70 \%$ alcohol for subsequent identification.

To obtain the flies, the contents of the traps were placed in plastic containers with a layer of sand to serve as a substrate for pupation of the larvae.
The sand was sifted 15 days after the traps were placed in the field, and the pupae were extracted from the sand and then placed individually in gelatin capsules (number 00) to obtain the flies. The flies' preferences for altitude and substrates were tested using ANOVA, with the data transformed to $\sqrt{ } \mathrm{x}+0.5$, using a $5 \%$ significance level.

Between August, 2003 and July, 2004, a total of 2,946 flies were collected, of which 1,255 were from an altitude of $740 \mathrm{~m}$ and 1,691 from an altitude of $1,000 \mathrm{~m}$ (Table 1). The flies did not present any preference between the traps placed at the altitudes of $740 \mathrm{~m}$ and $1,000 \mathrm{~m}(\mathrm{~F}=0.16$; $\mathrm{P}=0.6949$ ), probably due to the proximity of the traps to each other.

The altitude of $1,000 \mathrm{~m}$ presented greater richness of species (13 species collected) and abundance of flies (57.4\% of the flies collected), in comparison with the altitude of $740 \mathrm{~m}$. This was possibly because of the diversity of resources at this altitude. Recent studies on parasitoids have demonstrated different distribution patterns and richness when considering the altitude gradient (Shimbori et al., 2003).

At $740 \mathrm{~m}$ the most frequently found species was Oxysarcodexia thornax (Walker) (Diptera: Sarcophagidae), accounting for $42.4 \%$ of the individuals collected. In Itumbiara, state of Goiás, this species has been collected from bovine liver and feces (Marchiori et al., 2000; 2000a).

At $1,000 \mathrm{~m}$, the most frequently found species was Peckia chrysostoma (Wiedemann) (Diptera: Sarcophagidae), accounting for 27.6\%. Peckia chrysostoma is a synanthropic species found in various parts of the world (Ferraz, 1995). In Rio de Janeiro, this species demonstrated a preference for locations inhabited by man, and fish was the bait that presented the greatest attraction (D'Almeida, 1984). 
TABLE 1

Synanthropic flies collected at the altitudes of 740 and $1,000 \mathrm{~m}$, from different substrates in the Serra de Caldas Novas Park, state of Goiás from August 2003 to July 2004.

\begin{tabular}{|c|c|c|c|c|c|c|}
\hline \multirow{2}{*}{ Altitude/Family/Species } & \multicolumn{6}{|c|}{ Substrate } \\
\hline & Feces & Liver & Chicken & Fruit & Fish & Total \\
\hline \multicolumn{7}{|l|}{ Altitude of $740 \mathrm{~m}$ : } \\
\hline \multicolumn{7}{|l|}{ Calliphoridae: } \\
\hline Chrysomya albiceps & 10 & 30 & 0 & 0 & 4 & 44 \\
\hline Chrysomya megacephala & 1 & 0 & 0 & 0 & 0 & 1 \\
\hline \multicolumn{7}{|l|}{ Drosophilidae: } \\
\hline Drosophila sp. & 0 & 0 & 0 & 141 & 0 & 141 \\
\hline \multicolumn{7}{|l|}{ Fanniidae: } \\
\hline Fannia pusio & 236 & 0 & 0 & 0 & 0 & 236 \\
\hline \multicolumn{7}{|l|}{ Muscidae: } \\
\hline Brontaea sp. & 1 & 0 & 0 & 0 & 0 & 1 \\
\hline Musca domestica & 2 & 0 & 0 & 0 & 0 & 2 \\
\hline \multicolumn{7}{|l|}{ Sarcophagidae: } \\
\hline Oxysarcodexia thornax & 169 & 166 & 0 & 0 & 197 & 532 \\
\hline Peckia chrysostoma & 138 & 0 & 160 & 0 & 0 & 298 \\
\hline Total & 557 & 196 & 160 & 141 & 201 & 1255 \\
\hline \multicolumn{7}{|l|}{ Altitude of $1000 \mathrm{~m}$ : } \\
\hline \multicolumn{7}{|l|}{\begin{tabular}{|l|} 
Calliphoridae: \\
\end{tabular}} \\
\hline Chrysomya albiceps & 92 & 0 & 82 & 0 & 51 & 225 \\
\hline Chrysomya megacephala & 0 & 0 & 58 & 0 & 0 & 58 \\
\hline \multicolumn{7}{|l|}{ Drosophilidae: } \\
\hline Drosophila sp. & 0 & 0 & 0 & 66 & 0 & 66 \\
\hline \multicolumn{7}{|l|}{ Fanniidae: } \\
\hline Fannia pusio & 71 & 67 & 0 & 0 & 11 & 149 \\
\hline \multicolumn{7}{|l|}{ Muscidae: } \\
\hline Brontaea sp. & 10 & 0 & 0 & 0 & 0 & 10 \\
\hline Musca domestica & 130 & 0 & 61 & 0 & 0 & 191 \\
\hline Ophyra sp. & 74 & 25 & 23 & 0 & 0 & 122 \\
\hline Synthesiomya nudiseta & 57 & 0 & 0 & 1 & 0 & 58 \\
\hline \multicolumn{7}{|l|}{ Phoridae: } \\
\hline Megaselia scalaris & 0 & 114 & 0 & 0 & 0 & 114 \\
\hline \multicolumn{7}{|l|}{ Sarcophagidae: } \\
\hline Oxysarcodexia thornax & 0 & 17 & 101 & 0 & 16 & 134 \\
\hline Peckia chrysostoma & 117 & 99 & 62 & 0 & 189 & 467 \\
\hline Sarcodexia lambens & 50 & 0 & 0 & 10 & 36 & 96 \\
\hline Squamatoides trivittatus & 0 & 0 & 0 & 0 & 1 & 1 \\
\hline Total & 601 & 322 & 387 & 77 & 304 & 1691 \\
\hline TOTAL & 1158 & 518 & 547 & 218 & 505 & 2946 \\
\hline
\end{tabular}

With regard to altitude preference, none of these species presented any difference between the traps installed at $740 \mathrm{~m}(\mathrm{~F}=0.86 ; \mathrm{P}=0.5985)$ and $1,000 \mathrm{~m}(\mathrm{~F}=1.54 ; \mathrm{P}=0.3313)$. These flies did not also present any preference between the substrates at $740 \mathrm{~m}(\mathrm{~F}=0.40 ; \mathrm{P}=0.9314)$ and $1000 \mathrm{~m}$ $(\mathrm{F}=0.77 ; \mathrm{P}=0.7179)$.

According to Shimbori et al. (2003), each parasitoid genus (Braconidae) is influenced by altitude in a different manner. This demonstrates the 
complexity of the factors involved in variations due to altitude, in addition to the other environmental factors that are not directly related, such as human influence. This is probably what occurs in the case of synanthropic flies.

\section{REFERENCES}

D'ALMEIDA, J. M., 1984, Sinantropia de Sarcophagidae (Diptera) na região metropolitana do Estado do Rio de Janeiro. Arq. Univ. Fed. Rur. Rio de J., 7: 101-110.

FERRAZ, M. V., 1995, Larval and pupal periods of Peckia chrysostoma and Adiscochaeta ingens (Diptera: Sarcophagidae) reared under laboratory conditions. Mem. Inst. Oswaldo Cruz, 90: 611-614.

FERREIRA, M. J. M., 1978, Sinantropia de dípteros muscóideos de Curitiba, Paraná: Calliphoridae. Rev. Bras. Biol., 38: 445-454.

GREENBERG, B., 1971, Flies and disease - ecology, classification and biotic association. Princeton University Press, New Jersey, 856p.
GUIMARÃES, J. H., UCCI, E. C. \& BARROS-BATTESTI, D. M., 2001, Ectoparasitos de importância veterinária. São Paulo: Plêiade/FAPESP, 218p.

MARCHIORI, C. H, CASTRO, M. E. V, PAIVA T. C. G, SILVA C. G. \& TEIXEIRA, F. F., 2000, Dípteros muscóides de importância médica e veterinária e seus parasitóides em Goiás. Arq. Bras. Med. Vet. Zootec., 52: 350-353.

MARCHIORI, C. H, SILVA, C. G., CALDAS, E. R., VIEIRA, C. I. S, ALMEIDA, K. G. S, TEIXEIRA, F. F \& LINHARES A X., 2000a, Dípteros muscóides associados com carcaça de suíno e seus parasitóides em área de pastagem e de mata em Goiás. Arq. Bras. Med. Vet. Zootec., 52: 459-460.

MARCONDES, C. B, 2001, Entomologia Médica e Veterinária. Editora Atheneu, São Paulo, 432p.

SHIMBORI, E. M., YAMADA, M. V., PENTEADO-DIAS, A. M., 2003, Estudo da comunidade de Braconidae (Hymenoptera: Insecta) em diferentes altitudes no Parque Estadual do Jaraguá, Anais do $16^{a}$ Reunião Anual do Instituto Biológico, São Paulo, Brasil, 630p. 
